\title{
An Immunological Study of Bacillus subtilis Penicillinases
}

\author{
BY D. J. KUSHNER* \\ National Institute for Medical Research, Mill Hill, London N.W.7
}

(Received 14 May 1960)

SUMMARY

Antisera to the penicillinases of Bacillus subtilis strains 749 and 6346 were prepared, and the neutralization of enzymic activity by homologous and heterologous antisera was studied. Antisera to 749 penicillinase had, as expected, greater neutralizing power against 749 penicillinase than against 6346 penicillinase. A 6346 antiserum, however, neutralized the heterologous enzyme more effectively than the homologous enzyme, and was also more effective in precipitating heterologous than homologous enzymic activity. The penicillinases of $B$. subtilis, unlike those of $B$. cereus, could not be adsorbed on glass, but could be partially purified by calcium phosphate gel-adsorption. There was no cross-reaction, as measured by enzyme neutralization, between the penicillinases of $B$. subtilis and that of $B$. cereus 569 . Materials other than penicillinase in the enzyme preparations used did not interfere with the neutralization reactions between $B$. subtilis penicillinases and their antisera. The basal penicillinase produced by $\boldsymbol{B}$. subtilis $\mathbf{7 4 9}$ had the same neutralization curve, with a homologous antiserum, as did the induced enzyme.

\section{INTRODUCTION}

Immunological techniques have yielded results of great interest in studies of bacterial enzyme synthesis (see review by Cinader, 1957). Pollock (1956a) used the technique of specific enzyme neutralization by antibody to determine the immunological relations between the penicillinases of different Bacillus cereus strains. In a further study (Pollock, 1956 b), antisera to the penicillinase of B. cereus 569 were used to examine the location and properties of the cell-bound penicillinase produced by this organism. Recent results in this laboratory have suggested that similar immunological studies could profitably be carried out on the penicillinases produced by different strains of $\boldsymbol{B}$. subtilis. In $\boldsymbol{B}$. cereus, only about $10 \%$ of the total penicillinase formed is cell-bound, and the ratio of extracellular to cell-bound enzyme is constant throughout growth (Pollock, 1956 b). In contrast, the penicillinase formed by growing $B$. subtilis in the first $3 \mathrm{hr}$. after induction is almost totally cell-bound, and thereafter is slowly released into the external medium (Pollock, 1961). This organism, then, seemed especially suited for studies of the mechanism of penicillinase release, and it was felt that an antiserum to $B$. subtilis penicillinase would be of value in determining the location of the cell-bound enzyme and the properties of this and of the extracellular enzyme. This paper describes some of the properties of penicillinases from two strains of $\boldsymbol{B}$. subtilis, the preparation of antisera to these

* Present address : Cytogenetics Section, Forest Insect Laboratory, Sault Ste. Marie, Ontario, Canada. 
enzymes, and the effect of these antisera on penicillinase action. Immunological comparison has been made between the penicillinases of $B$. subtilis strains 6346 and 749 and the penicillinase from $B$. cereus 569 ; in addition, it has been possible to compare immunologically both the induced and the basal penicillinases formed by B. subtilis strain 749 .

\section{METHODS}

Bacteria. Bacillus subtilis 6346 was a gift from the late Dr E. Duthie; strain 749 was obtained from Distillers Company Limited, Liverpool.

Growth media. For strain 6346 a modification of the casein hydrolysate medium described by Kogut, Pollock \& Tridgell (1956) was used. Citrate was omitted, and trace metals ('oligodynamic solution' used by Pollock \& Kramer (1958), 0.1 ml./ $100 \mathrm{ml}$. medium) were added. For strain 749, this medium was supplemented with $0.02 \mathrm{M}$-citrate. Spores of each strain were incubated in $20 \mathrm{ml}$. growth medium, statically overnight at $35^{\circ}$ in $100 \mathrm{ml}$. Erlenmeyer flasks and then shaken on a reciprocal shaker ( 88 cycles/min., lateral throw of $3 \mathrm{in}$.) at $35^{\circ}$ until a culture density of about $1 \mathrm{mg} . / \mathrm{ml}$. was reached. Ten $\mathrm{ml}$. of such a culture were added to each of several 1 l. lots (in 5 l. flasks) of the same medium containing $0.5 \%$ glucose (for strain 6346) or $0.1 \%$ glucose (for strain 749 ). After $3 \mathrm{hr}$., when the culture density was $0 \cdot 05$ $0.1 \mathrm{mg} . / \mathrm{ml}$., $0 \cdot 1 \mathrm{unit} / \mathrm{ml}$. benzyl penicillin was added; and $2 \mathrm{hr}$. later, at a culture density of $0.5-0.7 \mathrm{mg} . / \mathrm{ml}$., $0.5 \mathrm{units} / \mathrm{ml}$. (strain 6346 ) or $1.0 \mathrm{unit} / \mathrm{ml}$. (strain 749 ) penicillin were added. Incubation was continued overnight (11-16 hr.). The 6346 culture supernatant fluid contained about 20 units penicillinase activity/ml., measured manometrically (Henry \& Housewright, 1947; Pollock, 1950), and the 749 culture supernatant fluid contained about 225 units $/ \mathrm{ml}$.

Concentration of Bacillus subtilis penicillinases. Preliminary investigations showed that adsorption by glass, which had proved most useful in purifying the penicillinase of $B$. cereus (Kogut et al. 1956) could not be applied to $B$. subtilis penicillinase. The addition of even a large amount of glass powder $(1 \cdot 0 \mathrm{~g}$. to $3 \cdot 0 \mathrm{ml}$. culture medium, over the $\mathrm{pH}$ range $5 \cdot 5-8 \cdot 1$ ) caused no diminution in the amount of soluble penicillinase present. The penicillinase in strain 6346 culture supernatant fluid was concentrated roughly 10 -fold by adding to the supernatant (adjusted to pH 5.5) 1/10 volume calcium phosphate gel (prepared according to Keilin \& Hartree, $1938 ; 19 \mathrm{mg} . / \mathrm{ml}$.), shaking intermittently for $1-2 \mathrm{hr}$. at room temperature and centrifuging. This procedure removed $90 \%$ of the penicillinase activity from the supernatant fluid. The gel was extracted three times with $1 / 5$ its volume M-phosphate buffer $\left(\mathrm{KH}_{2} \mathrm{PO}_{4}-\mathrm{Na}_{2} \mathrm{HPO}_{4} ; \mathrm{pH} 7 \cdot 0\right)$, the extracts dialysed against distilled water at $0^{\circ}$ until free from phosphate, and lyophilized. In a typical procedure, $1800 \mathrm{ml}$. of culture medium with activity $24 \cdot 2$ units $/ \mathrm{ml}$. yielded $244 \mathrm{mg}$. dried material with 118 units/mg. activity, a recovery of $66 \%$.

Calcium phosphate gel-adsorption was not a convenient method for concentrating 749 penicillinase. Approximately the same amount of penicillinase activity, per mg. gel, was adsorbed from the 749 as from the 6346 supernatants. Since the $\mathbf{7 4 9}$ cultures had ten times as much penicillinase activity, adsorption and elution, as described above, did not decrease the volume of solution containing enzymic activity. Strain 749 culture supernatant fluids were concentrated 10 -fold by evaporating under reduced pressure in a Craig rotary evaporator at $30-35^{\circ}$ (Craig, Gregory 
\& Hausmann, 1950). After dialysis, the soluble material was lyophilized. The $\mathbf{7 4 9}$ penicillinase was quite stable during this treatment. Five and one-half 1 . of culture medium containing 223 units activity $/ \mathrm{ml}$. yielded $1 \cdot 65 \mathrm{~g}$. dried material with 605 units activity/mg., an $80 \%$ recovery.

Uninduced enzyme preparation. For certain control experiments cultures of strains 6346 and 749 were prepared as outlined above, but without addition of penicillin. The culture supernatant fluids were concentrated in the same manner as those of induced cultures.

Immunization. (a) 6346 enzyme. Twenty-one mg. of a 6346 enzyme preparation (118 units activity $/ \mathrm{mg}$.) in a volume of $1.0 \mathrm{ml}$. Freund's adjuvant (Freund $\&$ McDermott, 1942; modified by the use of lanolin and light liquid paraffin B.P. instead of 'Aquaphor' and heavy paraffin oil) were injected into each thigh muscle of two rabbits $(6 \mathrm{~A}$ and $6 \mathrm{~B})$. After 4 weeks, each rabbit was given $13 \mathrm{mg}$. enzyme preparation intravenously ( $8 \mathrm{mg}$. ' alum-precipitated' enzyme/ml. prepared as described by Pollock, $1956 a$ ) over a period of a week. At this point, neutralization titres were still very low, and each rabbit was re-injected intramuscularly with about $10 \mathrm{mg}$. enzyme preparation in adjuvant. One month later, the rabbits were each given $45 \mathrm{mg}$. enzyme preparation (57 units/mg.) intravenously, as before, over a 2-weekperiod and after 1 week bled out and the sera separated. The sera are referred to as antisera $6 \mathrm{~A}$ and $6 \mathrm{~B}$.

(b) 749 enzyme. Either 150 or $125 \mathrm{mg}$. enzyme preparation (607 units/mg.) in adjuvant were injected into each thigh muscle of two rabbits $(9 \mathrm{~W}$ and $9 \mathrm{~S}$, respectively). After 6 weeks $(9 \mathrm{~W})$ or 3 weeks $(9 \mathrm{~S})$ each rabbit was injected intramuscularly with a further $\mathbf{2 3} \mathbf{~ m g}$. enzyme preparation in adjuvant. Four weeks later each rabbit was injected intravenously with about $200 \mathrm{mg}$. alum-precipitated enzyme over an additional 3 -week period and then bled out. The separated antisera are referred to as antisera $9 \mathrm{~W}$ and $9 \mathrm{~S}$. For the experiments reported here, the sera were not treated further. They showed no loss of neutralizing activity after being stored, frozen, for over 6 months.

Neutralization tests. Most neutralization tests were carried out in the Warburg vessel in which penicillinase activity was subsequently measured (Henry \& Housewright, 1947; Pollock, 1950). The enzyme and antiserum were mixed, usually in a total volume of $0.6 \mathrm{ml}$., and left together at room temperature for $20 \mathrm{~min}$. before adding bicarbonate, oxine gelatin $(0.00083 \mathrm{M}$-oxine in $1 \%, \mathrm{w} / \mathrm{v}$, gelatin) and water to a volume of $2.5 \mathrm{ml}$. It was found later, however, that the degree of neutralization was the same when the other components were added to enzyme and antiserum immediately after mixing. The period of contact between enzyme (6346 or 749 penicillinase) and antiserum $(9 \mathrm{~W})$ before addition of penicillin could be decreased to $10 \mathrm{~min}$., i.e. the time necessary for gassing and equilibration, or increased to $70 \mathrm{~min}$. without changing the observed degree of enzyme neutralization.

\section{RESULTS}

Enzyme neutralization with 749 antisera. The neutralization curves obtained when two different amounts of 749 penicillinase were each treated with increasing amounts of antiserum $9 \mathrm{~W}$ are shown in Fig. 1. Apart from the lower neutralization titre of the antiserum (units of enzyme neutralized per ml. of antiserum under conditions of 
enzyme excess, calculated from the slope of the linear portion of the neutralization curve) against the homologous enzyme, a significant difference must be noted between these and the curves obtained by Pollock (1956a) for purified Bacillus cereus 569 penicillinase and its antiserum. The latter neutralization curve was rectilinear over approximately $95 \%$ of its course, whereas with the $B$. subtilis $\mathbf{7 4 9}$

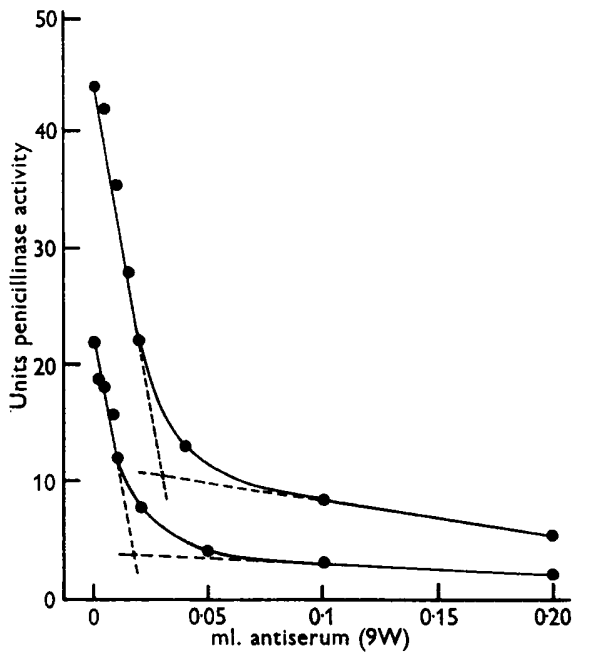

Fig. 1

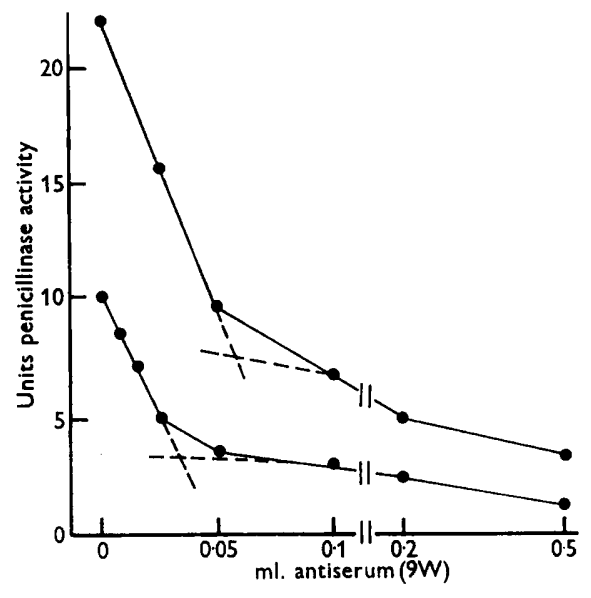

Fig. 2

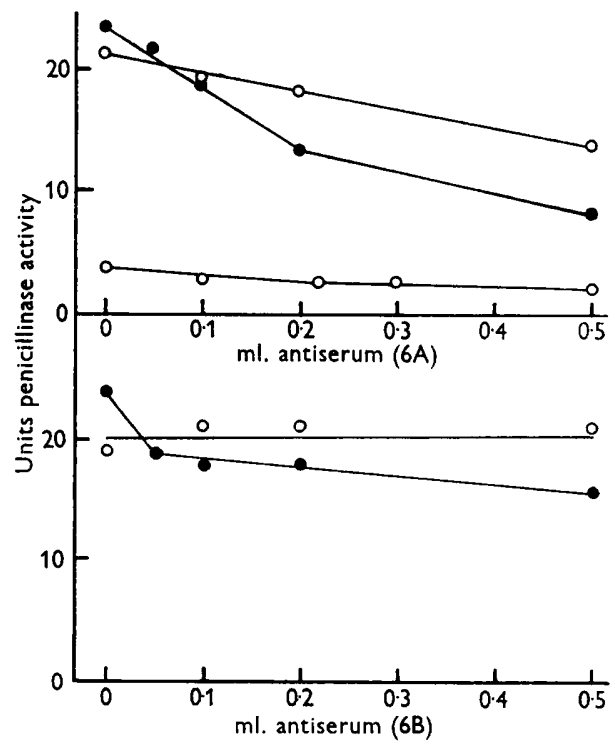

Fig. 3

Fig. 1. Neutralization curves of 749 penicillinase with 749 antiserum $(9 \mathrm{~W})$. Details as given in 'Methods'.

Fig. 2. Neutralization of 6346 penicillinase by 749 antiserum $(9 \mathrm{~W})$.

Fig. 3. Neutralization of $749-1$ and $6346 \bigcirc-O$ penicillinases with 6346 antisera (6A and $6 \mathrm{~B})$. 
enzyme it became curvilinear when only about $50 \%$ of penicillinase activity was neutralized and approached a residual value of $10 \%$ of the original activity with excess antibody. An approximation of the equivalence point for each amount of enzyme was obtained, as shown, by extrapolating the linear portion of the curve to meet a line joining the points in the region of antibody excess. The value found by this method (1.33 $\times 10^{3}$ units penicillinase per ml. antiserum) agreed, within $20 \%$, with that found by precipitation tests (Table 2 ). The two curves shown in Fig. 1 are parallel, indicating that the neutralization titre of the serum does not change with changing enzyme concentration.

Table 1. Cross-reactions between the penicillinases of Bacillus subtilis and Bacillus cereus measured by enzyme neutralization

The figures represent neutralization titre (units penicillinase neutralized by $1 \mathrm{ml}$. serum measured in the linear portion of the neutralization curve).

\begin{tabular}{|c|c|c|c|c|}
\hline \multirow[b]{2}{*}{ Enzyme } & \multicolumn{4}{|c|}{ Antiserum } \\
\hline & $749(9 W)$ & $346(6 A)$ & $569 *$ & $\begin{array}{c}\text { Normal } \\
\text { rabbit } \\
\text { serum }\end{array}$ \\
\hline $\begin{array}{l}\text { B. subtilis } \\
6346\end{array}$ & $\mathbf{2 4 4}$ & 15 & $\mathbf{0}$ & $\mathbf{0}$ \\
\hline 749 & 1085 & 50 & $\mathbf{0}$ & $\mathbf{0}$ \\
\hline $\begin{array}{c}\text { B. cereus } \\
569\end{array}$ & o & 0 & 21,300 & $\mathbf{0}$ \\
\hline
\end{tabular}

When 6346 penicillinase was treated with antiserum $9 \mathrm{~W}$ the neutralization curves obtained were similar in form to those obtained with the homologous enzyme (Fig. 2), but the neutralization titre of the 749 antiserum toward the 749 enzyme was $4 \cdot 8$ times as great as that of 749 antiserum toward the 6346 enzyme. Calculation of the equivalence point, as shown in Fig. 2, gives a mean value of $0 \cdot 32 \times 10^{3}$ units $/ \mathrm{ml}$. The value determined for the homologous inhibition is 4.2 times as great. Thus, there is close agreement between the comparative combining power of antiserum $9 \mathrm{~W}$ against homologous and heterologous enzyme, whether determined as antibody neutralization titre or calculated from the graphically determined equivalence point. Precipitation tests showed that only when 6346 penicillinase in excess of the equivalent amount was added to 749 antiserum did penicillinase activity appear in the supernatant fluid (Table 2).

The neutralization curve obtained by treating 749 and 6346 penicillinases with antiserum $9 \mathrm{~S}$ were similar in form to those obtained with antiserum $9 \mathrm{~W}$, but showed approximately twice the residual activity.

Enzyme neutralization with 6346 antisera. The 6346 antisera neutralized the homologous enzyme in one case (antiserum $6 \mathrm{~A}$ ) very weakly and in the other (antiserum 6B) not at all (Fig. 3). Surprisingly, however, the 6346 antisera had greater neutralizing power for the $\mathbf{7 4 9}$ penicillinase than for the homologous enzyme (Fig. 3), the neutralization titre being $\mathbf{3 \cdot 3}$ times as great (serum 6A). Possible reasons for this finding are discussed below.

Other cross-reactions. The effects of the above antisera and of the antiserum to purified Bacillus cereus 569 penicillinase on the action of $B$. subtilis and $B$. cereus 
Table 2. Precipitation of Bacillus subtilis penicillinase activity by antisera to 749 and 6346 penicillinase

Enzyme and antiserum were mixed in a final volume of $3.0 \mathrm{ml}$., containing $\mathbf{0 . 2 2} \mathrm{ml}$. $2 \mathrm{M}-\mathrm{NaCl}, 0.01 \mathrm{M}-$ phosphate buffer, $\mathrm{pH} \mathrm{7 \cdot 0}$, and $3 \cdot 3 \times 10^{-4} \mathrm{M}$-oxine and incubated overnight (16-20 hr.) at $35^{\circ}$. After centrifuging down precipitates and removing supernatant fuids, precipitates were washed once and then resuspended in buffered saline. Both original supernatant fluid and washed precipitate were analysed for penicillinase activity. In some experiments, residual neutralizing activity of the supernatant fluid was measured. The adsorbed antisera had first been incubated overnight at $35^{\circ}$ with $4 \mathrm{mg} . / \mathrm{ml}$. (serum $9 \mathrm{~W}$ ) or $1 \mathrm{mg} . / \mathrm{ml}$. (serum $6 \mathrm{~A}$ and $6 \mathrm{~B}$ ) of the appropriate uninduced preparation. These preparations contained 20 units/mg. (749) or $4 \cdot 4$ units/mg. (6346) basal penicillinase activity. The precipitates which formed were removed by centrifuging and the sera used as shown. The figures given are corrected for $\mathrm{CO}_{2}$ retention by the buffered saline.

\begin{tabular}{|c|c|c|c|c|c|c|c|}
\hline \multirow[b]{2}{*}{ Expt. } & \multirow[b]{2}{*}{ Antiserum } & \multirow[b]{2}{*}{$\begin{array}{l}\text { MI. anti- } \\
\text { serum } \\
\text { added }\end{array}$} & \multirow[b]{2}{*}{ Enzyme } & \multirow[b]{2}{*}{$\begin{array}{l}\text { Units } \\
\text { added }\end{array}$} & \multirow{2}{*}{$\begin{array}{c}\text { body } \\
\text { remaining } \\
\text { in super- } \\
\text { natant }(\%)\end{array}$} & \multicolumn{2}{|c|}{ activity in } \\
\hline & & & & & & $\begin{array}{l}\text { Super- } \\
\text { natant }\end{array}$ & $\begin{array}{l}\text { Precipi- } \\
\text { tate }\end{array}$ \\
\hline 1 & $749(9 W)$ & $0 \cdot 1$ & 749 & 95 & - & 4 & 11 \\
\hline & & & & 189 & - & 6 & 21 \\
\hline & & & & 378 & - & 62 & 2 \\
\hline 2 & $749(9 \mathrm{~W})$ & $0 \cdot 2$ & 749 & 111 & 30 & 4 & 13 \\
\hline & & & & 221 & 15 & 4 & 22 \\
\hline & & & & 332 & $\mathbf{0}$ & 12 & 27 \\
\hline 3 & $749(9 W)$ & 0.5 & 749 & 357 & 45 & $<1$ & 10 \\
\hline & & & & 535 & 28 & $<1$ & 14 \\
\hline & & & & 713 & 14 & 2 & 18 \\
\hline & & & & 892 & 1 & 6 & 19 \\
\hline & & & & 1070 & 2 & 30 & 12 \\
\hline 4 & $749(9 W)$ & $0 \cdot 2$ & 6346 & 16 & - & 6 & 10 \\
\hline & & & & 33 & - & 5 & 17 \\
\hline & & & & 49 & - & 3 & 20 \\
\hline & & & & 52 & - & $\mathbf{0}$ & 23 \\
\hline & & & & 80 & - & 22 & 8 \\
\hline & & & & 120 & 一 & 41 & 2 \\
\hline 5 & $6346(6 \mathrm{~A})$ & $0 \cdot 1$ & 6346 & 37 & - & 86 & 6 \\
\hline & & $0 \cdot 2$ & & 37 & $\ldots$ & 89 & 5 \\
\hline & & $0 \cdot 3$ & & 37 & - & 75 & 6 \\
\hline & & 0.5 & & 37 & - & 21 & 42 \\
\hline 6 & $6346(6 \mathrm{~A})$ & $1 \cdot 0$ & 6346 & 34 & - & 8 & 54 \\
\hline & & $\mathbf{2} \cdot 0$ & & 34 & - & 5 & 29 \\
\hline 7 & $6346(6 \mathrm{~B})$ & 0.5 & 6346 & 34 & - & 23 & 75 \\
\hline & & $1 \cdot 0$ & & 34 & - & 29 & 78 \\
\hline & & $2 \cdot 0$ & & 34 & - & 46 & 63 \\
\hline 8 & $6346(6 \mathrm{~B})$ & $1 \cdot 0$ & 6346 & 34 & - & 46 & 61 \\
\hline & & $\mathbf{2} \cdot 0$ & & 34 & - & 83 & 30 \\
\hline 9 & $6346(6 \mathrm{~A})$ & $0 \cdot 1$ & 749 & 37 & - & 65 & 31 \\
\hline & & $0 \cdot 2$ & & 37 & $\ldots$ & 18 & 49 \\
\hline & & $0 \cdot 3$ & & 37 & - & 18 & 34 \\
\hline & & 0.5 & & 37 & 一 & 10 & 7 \\
\hline & & $1 \cdot 0$ & & 37 & - & 9 & 3 \\
\hline & & $2 \cdot 0$ & & 37 & - & 2 & 2 \\
\hline 10 & $6346(6 \mathrm{~B})$ & $0 \cdot 2$ & 749 & 38 & - & 62 & 28 \\
\hline & & 0.5 & & 38 & - & 85 & 11 \\
\hline & & $1 \cdot 0$ & & 38 & - & 63 & 0 \\
\hline & & $\mathbf{2 \cdot 0}$ & & 38 & - & 63 & 0 \\
\hline
\end{tabular}

Neutral-

izing anti- Percent penicillinase body remaining 
Table 2 (cont.)

\begin{tabular}{|c|c|c|c|c|c|c|c|}
\hline \multirow[b]{2}{*}{ Expt. } & \multirow[b]{2}{*}{ Antiserum } & \multirow{2}{*}{$\begin{array}{l}\text { Ml. anti- } \\
\text { serum } \\
\text { added }\end{array}$} & \multirow[b]{2}{*}{ Enzyme } & \multirow[b]{2}{*}{$\begin{array}{l}\text { Units } \\
\text { added }\end{array}$} & \multirow{2}{*}{$\begin{array}{c}\text { Neutral- } \\
\text { izing anti- } \\
\text { body } \\
\text { remaining } \\
\text { in super- } \\
\text { natant }(\%)\end{array}$} & \multicolumn{2}{|c|}{$\begin{array}{l}\text { Percent penicillinase } \\
\text { activity in }\end{array}$} \\
\hline & & & & & & $\begin{array}{l}\text { Super- } \\
\text { natant }\end{array}$ & $\begin{array}{l}\text { Precipi- } \\
\text { tate }\end{array}$ \\
\hline \multirow[t]{2}{*}{11} & $749(9 \mathrm{~W})$ & $0 \cdot 35$ & 749 & 545 & - & 4 & 19 \\
\hline & $\begin{array}{c}749(9 \mathrm{~W}) \\
\text { (adsorbed)* }\end{array}$ & $0 \cdot 35$ & 749 & 545 & - & 9 & 18 \\
\hline \multirow[t]{6}{*}{12} & $6346(6 \mathrm{~A})$ & $0 \cdot 44$ & 6346 & 34 & - & 75 & 16 \\
\hline & (adsorbed)* & $0 \cdot 88$ & & 34 & $\ldots$ & $\mathbf{0}$ & 62 \\
\hline & & $1 \cdot 8$ & & 34 & - & 3 & 45 \\
\hline & $6346(6 \mathrm{~B})$ & $0 \cdot 44$ & 6346 & 34 & - & 31 & 69 \\
\hline & (adsorbed)* & $0 \cdot 88$ & & 34 & - & 53 & 54 \\
\hline & & $1 \cdot 8$ & & 34 & - & 76 & 28 \\
\hline
\end{tabular}

* Neutralization tests showed that adsorption by uninduced preparations caused a $20 \%$ reduction in neutralizing power of serum $6 \mathrm{~A}$ and no measurable reduction in that of serum $9 \mathrm{~W}$.

enzymes are summarized in Table 1 . It is seen that there was no cross reaction, as measured by enzyme neutralization, between the penicillinases of the two bacterial species.

\section{The effect of uninduced culture supernatant fluids on the neutralizing power of antisera}

Since impure enzyme preparations were used throughout this work, the possibility arose that substances other than the enzyme itself might be influencing the reaction between enzyme and antiserum. This was investigated by measuring the effect of material from uninduced cultures on the neutralization reactions. Such material is thought to be the same as that found in an induced culture, lacking only induced penicillinase. Addition to the 6346 or 749 enzyme preparation of an equal or greater weight of the corresponding uninduced culture preparation did not affect the neutralization of either enzyme by homologous or heterologous antisera (Fig. 4).

\section{Precipitation of penicillinase activity with antisera}

When the Bacillus subtilis enzyme preparations were mixed with antisera and incubated overnight at $35^{\circ}$, precipitates possessing different degrees of penicillinase activity were formed. No precipitates were formed with normal rabbit serum. The results of representative experiments, in which different proportions of homologous and heterologous antisera were mixed with 749 and 6346 penicillinase, are presented in Table 2. The following were the main findings.

(1) With 749 penicillinase and its antiserum $(9 \mathrm{~W})$, the activity of the precipitate formed varied with changing enzyme-antibody ratio. It was approximately $10 \%$ in the presence of large antibody excess, corresponding to the residual activity found in neutralization curves (Fig. 1), and rose to $20 \%$ or more at the equivalence point (determined by the simultaneous disappearance of antibody from, and appearance of antigen in, the supernatant). As the proportion of enzyme was further increased, less activity was found in the precipitate; virtually no activity was found in precipitates formed in the presence of a large excess of penicillinase. This failure of a precipitate to form in the presence of large antigen excess is characteristic of 
other antigen-antibody combinations (Boyd, 1956). Antiserum 9S gave results similar to those obtained with serum $9 \mathrm{~W}$. The active precipitate formed by the combination of 749 penicillinase with antiserum $9 \mathrm{~W}$ proved, as did the precipitate formed between Bacillus cereus 569 penicillinase and its antiserum (Pollock, 1956a), quite stable to repeated washing in buffered saline.

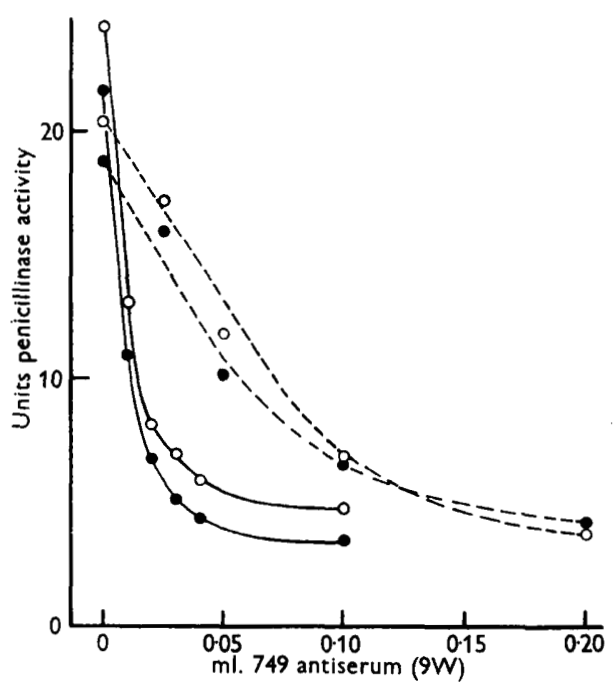

Fig. $4 a$

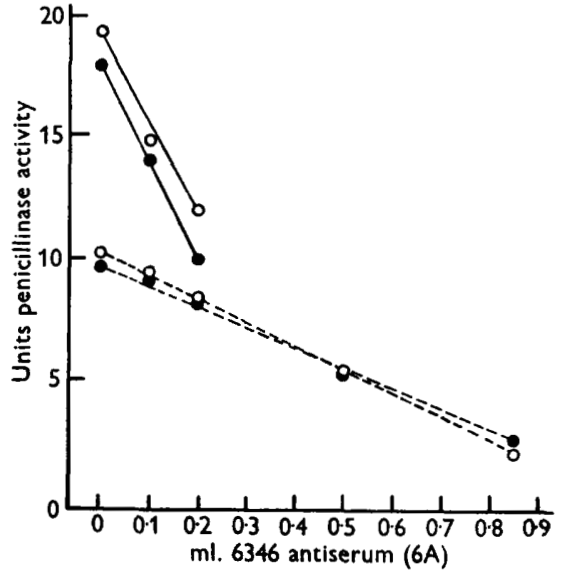

Fig. $4 b$

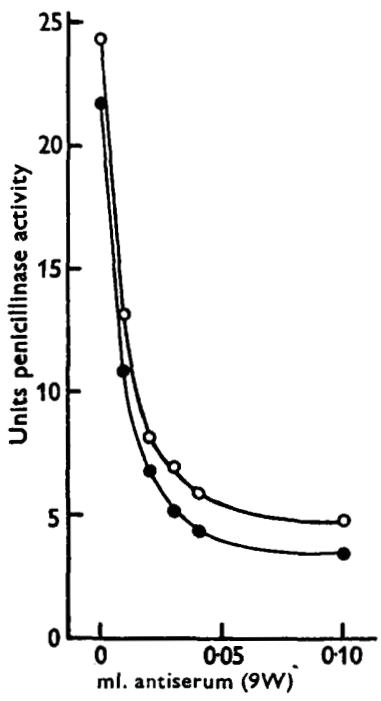

Fig. 5

Figs. $4 a, b$. Effect of preparations from uninduced cultures on neutralization of penicillinase by 749 antiserum $9 \mathrm{~W}(4, a)$ and 6346 antiserum $6 \mathrm{~A}(4, b): 749$ penicillinase $(0 \cdot 05 \mathrm{mg})$ - 7749 penicillinase + uninduced 749 preparation $(0.05 \mathrm{mg}$.) $\mathrm{O}-\mathrm{O}$; 6346 penicillinase $(0.3 \mathrm{mg}$. in $4 a ; 0.15 \mathrm{mg}$. in $4 b)$-.- ; 6346 penicillinase + uninduced $6346 \mathrm{prep}$ aration $(0.5 \mathrm{mg}$. in $4 a ; 0.2 \mathrm{mg}$. in $4 b) 0 \cdots 0$.

Fig. 5. Neutralization of basal and induced 749 penicillinase by 749 antiserum $9 \mathrm{~W}$. Induced penicillinase ( $0.06 \mathrm{mg}$.) - - Basal penicillinase $(1.0 \mathrm{mg}.) \mathrm{O}-\mathrm{O}$. 
(2) Precipitates having penicillinase activity were also formed between the 6346 enzyme preparation and the 749 antiserum $9 \mathrm{~W}$. The activity of these precipitates varied with changing enzyme: antibody ratio in a manner similar to that of the precipitates formed between $\mathbf{7 4 9}$ penicillinase and antiserum $9 \mathrm{~W}$.

(3) As already noted (Fig. 3), 6346 antisera had a greater inhibitory action on 749 penicillinase than on 6346 penicillinase. It was also found that serum $6 \mathrm{~A}$ had a greater precipitating power with the heterologous than with the homologous enzyme. For example, $0.2 \mathrm{ml}$. of this serum removed 30 units of 749 penicillinase activity from the supernatant fluid but only 4 units of 6346 penicillinase activity (Table 2; Expts. 5 and 9). The actual amount of enzyme precipitated cannot be determined from these experiments, but it is evident that not more than 4 units of 6346 penicillinase and not less than 18 units of 749 penicillinase were precipitated by $0.2 \mathrm{ml}$. serum $6 \mathrm{~A}$. Thus, the difference in combining power of antiserum $6 \mathrm{~A}$ with the heterologous and homologous enzymes was slightly larger than the respective difference in neutralization titre (Fig. 3). Certain precipitates formed in the presence of serum $6 \mathrm{~A}$ had much more penicillinase activity than precipitates formed in the presence of 749 antisera, some containing more than $50 \%$ original activity. With increasing amounts of antiserum, the activity of these precipitates decreased.

(4) Striking, though not easily interpretable, results were obtained with antiserum $6 \mathrm{~B}$. This serum had previously been found to have no inhibitory action on 6346 penicillinase and only a slight action on 749 penicillinase (Fig. 3). The lack of inhibition of the homologous enzyme, however, was not due to a lack of combining power, but to the fact that antibody in this serum combined with the enzyme without lowering its activity. Thus, precipitates with almost $80 \%$ original enzymic activity could be obtained, the remainder of the penicillinase activity remaining in solution. With increasing amounts of antiserum, however, less activity was precipitated; because of this, it seemed difficult to estimate the combining power of this serum. Significant amounts of 749 penicillinase activity could be precipitated by serum $6 \mathrm{~B}$, but with increasing amounts of serum, either the precipitate formed was inactive, or no enzyme was precipitated. Since the neutralizing power of serum $6 \mathrm{~B}$ was low and its precipitation reactions obscure, further work was not done with this serum.

(5) The penicillinase preparations used had not been purified, and the antisera must have contained antibodies other than those to penicillinase. An attempt was made to purify the antisera, at least partially, by incubating them overnight with material from the appropriate uninduced culture supernatant fluid and removing the large precipitate that formed. These adsorbed antisera caused precipitates to form with approximately the same penicillinase activity as those formed in experiments with corresponding amounts of untreated antisera (Expts. 11 and 12).

\section{Immunological comparison of basal and induced 749 penicillinase}

The uninduced 749 culture had a measurable basal penicillinase activity, approximately one-fifteenth that of the induced culture. The neutralization curve of the basal enzyme by 749 antiserum was parallel throughout its course with that of the induced enzyme (Fig. 5), indicating that, as with Bacillus cereus 569 (Pollock, 1956a), basal and induced enzymes are immunologically indistinguishable. 


\section{DISCUSSION}

There is no obvious explanation for the curious fact that the antiserum from rabbit $A$, the most active of the two 6346 antisera obtained, both precipitated and neutralized the heterologous enzyme more effectively than it did the homologous enzyme. The combining power of 6346 penicillinase, even with its own antiserum, thus seems to be lower than that of the $\mathbf{7 4 9}$ penicillinase, unless it is possible that in these experiments combination did not necessarily lead to precipitation, or unless one makes the assumption that the specific activity of 6346 penicillinase is much lower than that of $\mathbf{7 4 9}$ penicillinase. In the latter case, combination with more molecules of 6346 penicillinase than of 749 penicillinase would be necessary for the same degree of enzyme inhibition. Such a large difference in specific activity between similar enzymes from closely related species would appear unusual (Dixon \& Webh, 1958, p. 653), but certainly not impossible, since catalytically similar enzymes with different specific activities may be formed by the same species (Brown, 1952; Neilands, 1952). Thus, ox liver has been reported to contain two catalases possessing a fourfold difference in specific activity (Brown, 1952). It should be noted, however, that the difference in specific activity (on a molecular basis) between the immunologically distinct penicillinases of Bacillus cereus 569 and B. cereus $5 / \mathrm{B}$ is only $20 \%$ (Kogut et al. 1956).

If differences in combining power of the two Bacillus subtilis penicillinases do, in fact, account for the anomalous cross-reactions observed, the following possibility might be considered. It is reasonable to suppose that the antigenically active groups shared by the two types of penicillinases could differ somewhat in their ability to combine with the antibody against these groups. This difference might be such that the antigenically active groups on the 749 enzyme were more 'exposed' (or for other reasons more reactive) than those on the 6346 penicillinase, and possibly the combination of antibody with such groups would inhibit enzyme activity more effectively. In such a case the $\mathbf{7 4 9}$ enzyme might combine more effectively with a higher proportion of the specific antibody (even when induced by the heterologous 6346 penicillinase) than could the 6346 penicillinase itself. There seems to be no theoretical objection to such an apparently paradoxical situation arising occasionally; although it might be expected to be infrequent. To determine precisely what differences between the two penicillinases might account for their anomalous crossreactions, it would be necessary to have both enzymes in a pure form.

The fact that purified enzymes were not available for this work has made it necessary to view with caution some of the results, especially those showing that precipitates possessing a wide range of penicillinase activity may be formed between different combinations of Bacillus subtilis penicillinases with their antisera. Since the rabbits had been injected with a mixture of proteins, their sera must have contained antibodies other than those against penicillinase, and it seemed possible that formation of precipitates with penicillinase activity might be due to a nonspecific co-precipitation of penicillinase by other antigen + antibody pairs present rather than to penicillinase + antipenicillinase interaction. Although this possibility has not been rigidly excluded, it appears highly unlikely for the following reasons.

(1) With an increasing antigen: antibody ratio, 749 penicillinase activity appears in the supernatant fluid at the same time as neutralizing antibody disappears 
(Table 2). A close correspondence between the two events, characteristic of antigen + antibody combination, would not be expected if removal of enzymic activity were chiefly by co-precipitation.

(2) Antisera adsorbed with uninduced culture preparations, in order to remove antibodies other than antipenicillinases, formed precipitates possessing approximately as much penicillinase activity as those formed with untreated antisera (Table 2).

(3) Bacillus subtilis penicillinases were not carried down by the precipitates formed between defined antigen + antibody pairs. It was found that the precipitation of Pneumococcal Type III polysaccharide, of human gamma globulin, and of ovalbumin by their specific (rabbit) antisera (generously given by Dr J. H. Humphrey and $\operatorname{Dr}$ B. A. Askonas) in the presence of 6346 or 749 penicillinase did not remove any penicillinase activity from solution.

For these reasons, the enzymic activity of the precipitates formed when penicillinase preparations were mixed with antisera is considered a measure of the activity of the enzyme + antibody complex. The formation of such an active complex is of special interest in considering the inhibitory pattern of the 6346 antisera. Rabbits injected with 6346 penicillinase over a prolonged period gave discouragingly low titres of antibody activity, as measured by 6346 penicillinase neutralization (rabbit A), or had no neutralizing ability at all (rabbit B). Precipitation tests showed, however, that the reaction between 6346 antisera and the homologous enzyme was greater than indicated by enzyme inhibition alone, and that combination with antibody (as indicated by precipitation) could take place with little or no accompanying inactivation. A considerable difference in enzymic activity of penicillinase + antipenicillinase precipitates in two Bacillus cereus strains was observed earlier (Pollock, 1956a); strain 569 penicillinase formed a precipitate with less than $5 \%$ original activity, whereas strain $\mathbf{5} / \mathbf{B}$ penicillinase formed a precipitate with over $50 \%$ original activity, with the homologous antiserum.

Cinader (1957) emphasized that combination of an enzyme with its antibody may or may not lead to inactivation and that, in general, active precipitates may be formed only with those enzymes possessing low molecular weight substrates. The studies reported here and the earlier work of Pollock (1956a) have emphasized how the degree of inactivation can also depend on the properties of the enzyme and antibody involved. Depending on the bacterial strain producing the enzyme and the antiserum used, one may obtain a series of enzyme + antibody precipitates in which enzyme activity is absent, or is almost completely unimpaired.

I am deeply indebted to Dr M. R. Pollock for first suggesting this problem and for many discussions during the course of the work; to Dr J. H. Humphrey for invaluable advice on immunological techniques and for discussing the results obtained. Miss Ruth Coyle and Mr Richard Pearce provided expert technical assistance. Experimental studies were carried out through a work transfer under the Research Branch, Canada Department of Agriculture, from the Cytogenetics Section, Forest Insect Laboratory, Sault Ste. Marie, Ontario, Canada. 


\section{REFERENCES}

BoyD, W. C. (1956). Fundamentals of Immunology, 3rd ed. New York: Interscience Publishers Inc.

Brown, G. L. (1952). A solubility analysis of crystalline ox-liver catalase. Biochem. J. $51,569$.

Cinader, B. (1957). Antibodies against enzymes. Annu. Rev. Microbiol. $11,3 \% 1$.

Craig, L. C., Gregory, J. D. \& Hausmann, W. (1950). Versatile laboratory concentration device. Anal. Chem. 22, 1462.

Drxon, M. \& WebB, E. C. (1958). Enzymes. London: Longmans, Green and Co.

Freund, J. \& McDermotr, K. (1942). Sensitization to horse serum by means of adjuvants. Proc. Soc. exp. Biol., N.Y. 49, 548.

Henry, R. J. \& Housewright, R. D. (1947). Studies in penicillinase. II. Manometric method of assaying penicillinase and penicillin, kinetics of the penicillin-penicillinase reaction and the effect of inhibitors on penicillinase. J. biol. Chem. 167, 559 .

Keilin, D. \& Hartree, E. F. (1938). On the mechanism of the decomposition of hydrogen peroxide by catalase. Proc. roy. Soc. B, 124, 397.

Kogut, M., Pollock, M. R. \& Tridgeld, E. J. (1956). Purification of penicillin-induced penicillinase of Bacillus cereus NRRL 569: a comparison of its properties with those of a similarly purified penicillinase produced spontaneously by a constitutive mutant strain. Biochem. J. 62, 391.

Nerlands, J. B. (1952). Studies on lactic dehydrogenase of heart I. Purity, kinetics and equilibria. J. biol. Chem. 199, 373.

Pollock, M. R. (1950). Penicillinase adaptation in B. cereus: Adaptive enzyme formation in the absence of free substrate. Brit. J. exp. Path. 31, 739.

Pollock, M. R. $(1956 a)$. An immunological study of the constitutive and penicillininduced penicillinases of Bacillus cereus, based on specific enzyme neutralization by antibody. J. gen. Microbiol. 14, 90.

Poulock, M. R. (1956b). The cell-bound penicillinase of Bacillus cereus. J. gen. Microbiol. $15,154$.

Poulock, M. R. (1961). Exo-enzymes. In The Bacteria, vol. 4 (ed. I. C. Gunsalus \& R. Y. Stanier). New York: Academic Press Inc.

Pollock, M. R. \& Kramer, M. (1958). Intermediates in the biosynthesis of bacterial penicillinase. Biochem. J. 70, 665. 